\title{
The dynamics of locational patterns of brazilian manufacturing industry in 2012
}

\author{
Rafaella Stradiotto Vignandi ${ }^{1}$ \\ Tomás Amaral Torezani ${ }^{2}$ \\ José Luiz Parré ${ }^{3}$
}

\begin{abstract}
The purpose of this paper is to present and analyze the dynamics of locational patterns of the Brazilian manufacturing industry regarding the Krugman's specialization index and Gini's concentration index of industrial sectors, of the 558 Brazilian's micro-regions in the year of 2012. The used variable consists in the formal labor of the divisions that compounds the manufacturing industry. In order to detect the spatial patterns of indicators of interest behavior, corroborating, or not with the influence of the environment and space on them, spatial econometrics has been applied. The values of the global Moran's I of the two indexes imply the rejection of the null hypothesis of absence of spatial autocorrelation. Thus, there are also clusters of well-defined High-High and Low-Low patterns, and a lower number of High-Low and High-Low patterns. The obtained results allow the identification of micro-regions that showed a highly specialized productive structure and others with a high degree of diversification.
\end{abstract}

Keywords: Krugman's specialization index; Gini’s concentration index; Clusters.

\footnotetext{
JEL: R11, R12

$1 \mathrm{MSc}$ in Economics at State University of Maringá (PCE/UEM, Brazil). PhD student in Economics at Federal University of Minas Gerais (CEDEPLAR/UFMG, Brazil). Scholarship from CAPES. E-mail: rafaellasv@gmail. com

2 MSc in Economics at State University of Maringá (PCE/UEM, Brazil). PhD student in Economics at Federal University of Rio Grande do Sul (PPGE/UFRGS, Brazil). Scholarship from CAPES. E-mail: tomas_torezani@ hotmail.com

3 Doctor in Applied Economics from University of São Paulo (USP/ESALQ). Professor, Department of Economics and Masters/Doctorate Program in Economics, State University of Maringá (UEM). Phone: (o44) 3261-4905. E-mail: jlparre@uem.br
} 


\title{
A dinâmica dos padrões de localização da indústria manufatureira do brasil em 2012
}

\begin{abstract}
Resumo: O propósito do presente artigo é apresentar e analisar a dinâmica dos padrões de localização da indústria considerando os índices de especialização de Krugman e concentração de Gini, em relação aos setores da indústria de transformação, para as 558 microrregiões brasileiras no ano de 2012. A variável utilizada consiste no emprego formal das divisões que compõem a indústria de transformação. Emprega-se a econometria espacial para detectar padrões espaciais de comportamento dos indicadores de interesse, corroborando, ou não, a influência do meio e do espaço sobre eles. Os valores do I de Moran global dos dois índices implicam na rejeição da hipótese nula de ausência de autocorrelação espacial. Dessa forma, constatam-se clusters bem definidos do padrão Alto-Alto e Baixo-Baixo e, em menor número, de configurações Alto-Baixo e Baixo-Alto. Os resultados obtidos permitem identificar microrregiões que apresentaram uma estrutura produtiva fortemente especializada e outras com um elevado grau de diversificação.
\end{abstract}

Palavras-chave: Índice de especialização de Krugman; Índice de concentração de Gini; Clusters.

JEL: R11, R12

\section{Introduction}

The Economic Geography seeks to explain the location, distribution and organization of economic activities in space in any geographical unit, be it a country, a macro region, meso region, micro-region or municipality. The recent geographical analysis of these economic activities has been emphasizing the importance of spatial proximity to the development of processes to generate and disseminate new knowledge and capabilities among economic agents, once the decision of location of a firm generates patterns of spatial distribution of a particular industry as the emergence of productive agglomerations.

Studies on the location of productive agglomerations in space have been developed since the work of Marshall (1920). The author identifies on the externalities - external economies - the sources for industrial growth and employment in a given region, which means the existence of increasing economical returns - agglomeration economies - in the ambit of the industry.

Hoover (1948), from the Marshallian analysis, ranks the agglomeration eco- 
nomies: (i) localization economies, which are the advantages resulting from the proximity of firms that operate in the same branch of industry in a specific region, and are based on the ideas of Marshall (1920); and (ii) economies of urbanization or Jacobian economies, which are the benefits generated by the clustering of firms from different branches of industry in the same region, having as main reference the theories of Jacobs (1969).

From the 1990s, studies and debates of regional issues of industrial spatial location in mainstream academic scenario were intensified. These studies make the use of Krugman (1991a, 1991b), Venables (1996), Fujita, Krugman and Venables (2002) and Fujita and Thisse (2002) works as the core of what became known as the New Economic Geography. This theoretical model put the microeconomic foundations together with the existing theories and has in the findings of scale increasing returns - technological and pecuniary externalities - the explanation of economic agglomerations as determinants of clustering. According to this approach, the location and spatial configuration of economic activities depend on the outcome of the process between centripetal and centrifugal forces. The centripetal forces leading to agglomeration of these activities in a particular region and generate benefits to the location of firms, once centrifugal forces lead to the deconcentration of these economic activities.

Regarding the agglomerative forces, the attractiveness of urban areas is associated with both offered opportunities, such as varieties of products, labor supply and public services and the existence of urban economies of scale or agglomeration economies, originated from positive externalities generated by the concentration of firms and people in specific areas, despite the inefficiencies typically associated with large cities (Amarante and Batista da Silva, 2011). In addition, other economies of scale, such as reduction of transportation costs, increasing mobility of production factors and greater diffusion of knowledge for firms included in this context, also act as inductive factors for agglomeration. Moreover, especially in Brazil, the adoption of policies, industrial incentives and investments by the government stands out as an attractiveness of an urban space.

Two important elements to identify a productive agglomeration are the indexes of industrial specialization and concentration. According to Basso, Silva Neto and Stoffel (2005), the characterization of the geographic distribution of economic activities and their degree of specialization and concentration is an important step for understanding the dynamics present in local development processes. Thus, having a proper diagnosis of the productive dynamic specificities becomes important to support projects and local development policies, hence justifying the effort to identify the degree of specialization and concentration of industrial sectors to qualify the geographical and sectional clusters of firms that can be enhanced by deliberate joint actions, in terms of increasing cooperation between firms or guiding public policies.

According to Silveira Neto (2005), the notion of specialization corresponds 
to the distinction between the regional industrial structures, whereas concentration refers to the distinction of geographic presence of each branch of industry. From the use of the same source of information - for instance, employment levels - the two notions together enable people to apprehend both differences in industrial structure between regions (specialization) and evidence of local tendencies of specific branches of industries from such regions (concentration).

Along these lines, this study aims to present and analyze the spatial distribution of the indexes of specialization and concentration of the sectors of manufacturing industry in the micro-regions in Brazil in 2012. Therefore, we calculated the Krugman's index and the Gini's index to examine, respectively, the specialization and the concentration in relation to the sectors of manufacturing industry in the year of analysis. It is used then the spatial econometrics, through the Exploratory Spatial Data Analysis (ESDA), to describe the spatial distribution, the spatial association patterns (clusters), verify the existence of different forms of instability (non-stationary) and identify not usual observations such as the number of outliers.

As for the structure of the article, it covers in addition to this introduction, three sections. Section 2 presents the Krugman's index and the Gini's index to determine, respectively, levels of specialization and concentration of manufacturing industry in Brazil in 2012, and clarifies the spatial econometric techniques used in this study, namely the ESDA, observing the spatial weight matrices, the univariate global spatial autocorrelation, the Moran diagram and LISA indicators. Section 3 comprises the results and discussions of the study, performing an univariate analysis of the Krugman's index and the Gini's index considering the year of analysis. Finally, the last section comprehends the exposure of final considerations.

\section{Important studies}

In this paper, we tried to methodically study the main indicators used as comparative concentration, the Gini index and the Krugman specialization index (which measures the disparity from one region against the other).In general, the Gini index is used to measure the concentration of an industry (Haddad, 1989). Among the various examples of possible applications of this indicator, we highlight the work of Suzigan et al. (2001), where the Gini indexes and Locational Quotients (LQs) are used to identify and map the existence of clusters of firms in the state of São Paulo.

The Krugman specialization index is an indicator of the disparity between the kind of concentration of productive activity in a region relative to the productive structure of the database that you want to compare. In this sense, it represents a good measure of the effects of specialization even in regions 
with very complex industrial structure (Krugman, 1991). One of the studies that makes an interesting application of the K-index for the analysis of regions of specialization is to Crescenzi et al. (2007), in which the authors applied the index to regions in the United States and Europe in order to measure the role of specialization of the productive structure of the regions located on the flows of knowledge that are generated between agents.

The study Midelfart Knarvik et al. (2000) also makes a very interesting application of the K-index. Through the index, the authors analyze the time evolution of the regional distribution of industrial activity in Europe. Thus, it is used to quantitatively measure the specialization of European Union countries over time. The indicator is used as the principal measure of specialization in industrial structure of fourteen member countries of the European Union for four sets of years: 1970-73; 1980-83, 1989-91 and 1994-97. The variation of this indicator over the years points to change the configuration of each industrial member countries facing other European Union members. An elevation between periods indicates a movement defined specialization of industrial structure in relation to others. Moreover, a reduction of the indicator shows a movement towards or homogenization of industrial activity in the country against the productive structure of the European Union as a whole. Furthermore, the magnitude of the index is also an important indicator, because it shows how the industrial structure of each country differs in relation to industrial activity throughout Europe.

In this paper, the measure of expertise was carried out according to work-Midelfart Knarvik et al. (2000). For each region analyzed was calculated involvement of employees of a particular division of the manufacturing industry in total employment in all classes of each micro and participation of employees in the rest of the micro, or even the participation of employees in the industry outside the region already calculated. Thus, it was possible to obtain an approximation of the economic size of each region in economic activity compared to all the rest of the regions.

In a study by Silveira Neto (2005), are presented empirical evidence on levels and trends of geographical concentration and specialization of industrial activity in Brazil for the period 1950-2000 and on the explanatory power of economic arguments related to Economic Geography for such levels and trends observed. Although they indicate the importance of factors specific to industries considered, the evidence obtained supports the arguments in favor of the concentration present in models based on increasing returns to scale with transportation costs (Krugman, 1991). 


\section{Methodology}

This section aims to present the methodology used to measure the level of sectional specialization and concentration of manufacturing industry of Brazilian micro-regions in 2012, as well as investigate and analyze the dynamics of their locational patterns in space. In order to calculate the indexes of Krugman's specialization and Gini's concentration, the variable formal employment for the year 2012 was used. This variable was collected from the 24 divisions of the manufacturing industry sectors recognized by the National Classification of Economic Activities (CNAE 2.0) in 558 Brazilian micro-regions, according to the division proposed by the Brazilian Institute of Geography and Statistics (IBGE). This basis of secondary data was obtained through the Social Information Yearbook (RAIS) from Ministry of Labor and Employment (MTE).

As stated in the formulas for calculating the indicators presented in the following subsections, it was determined both a partial relation of jobs in each of the 24 divisions of the manufacturing industry for the 558 Brazilian micro-regions and as well as the sum of this relationship, resulting in micro-regional global indexes of productive specialization and industrial concentration. Thus, the Krugman's global index refers to the relative importance of productive specialization, while the Gini's global index refers to the absolute importance of industrial concentration, taking into account all the 24 divisions of the sectors of manufacturing industry and the 558 Brazilian micro-regions for a more detailed analysis of these processes in the delimited space.

\subsection{Indicators of industrial specialization and concentration}

Initially it is worth noting that although these two indexes answer the following raised questions, both use distinct methods, because the Krugman's index makes a comparative evaluation with other micro-regions, while the Gini's index is an internal evaluation of the industrial structure of each micro-region. In other words, the Krugman's index evaluates one micro-region in relation to others, whereas the Gini's index evaluates each micro-region alone. It is possible that a micro-region gets a Gini's index equal to zero, which would lead to a homogeneous distribution of industrial production between sectors, while having a high Krugman's index. Likewise, one micro-region may have a Krugman's index equal to zero, which would lead to a non-specialization of the industry, but having a Gini's index near one. In the latter case, the structure of industrial production in the country as a whole is also very concentrated in some sectors. 


\subsubsection{Krugman's specialization index}

The Krugman's index (K) shows the degree of specialization of micro-regions by calculating the sum of absolute difference between the participation of the $\mathrm{k}$-nth sector in industrial production of the $\mathrm{i}$-nth state and the average of the relative share of this industrial sector in the remaining micro-regions. In general, the method of calculation can be represented by the following formula:

$$
K_{i}(t)=\sum_{k} a b s\left(v_{i}^{k}(t)-\overline{v_{i}^{k}}(t)\right)
$$

in which:

$$
v_{i}^{k}(t)=\frac{x_{i}^{k}(t)}{\sum k^{x_{i}^{k}(t)}}
$$

$x_{i}^{k}(t)$ is the value of the manufacturing industry of the micro-region $i$ in the industry $\mathrm{k}$ at the time $\mathrm{t}$; and

$$
\overline{v_{i}^{k}}(t)=\frac{\sum_{j} \neq x_{j}^{k}(t)}{\sum k \sum_{j} \neq i^{x_{j(t)}^{k}}}
$$

This index takes a minimum value of zero when the relative industrial structure on the i-nth micro-region is equal to the other micro-regions (and a maximum of two when this structure is totally different from the other micro-regions). It is worth remembering that the Krugman's index measures the degree of relative specialization compared to the rest of the economy, not the absolute degree of specialization ${ }^{1}$. Hence, if all the regions only manufacture products from the same segment, they will present null index of relative specialization, but will have a high absolute level of specialization.

\subsubsection{Gini's concentration index}

To evaluate how the industrial structure of a specific micro-region is concentrated; the Gini's index (G) can be used. The sub divisions should be permutated in ascending order for the index calculation. This index is defined by the following formula:

$$
G_{i}=1-\frac{1}{T} \sum_{j=1}^{T}\left(\phi_{i}^{j-1}+\phi_{i}^{j}\right)
$$

1 In order to measure the degree of absolute specialization, the Gini's index (G) is used, which can also be represented by the formula: . 
in which:

$$
\phi_{i}^{j}=\frac{\sum_{k=1}^{j} x_{i}^{k}}{\sum_{j=1}^{T} x_{i}^{j}}
$$

is the accumulated distribution up to the $\mathrm{j}$-nth sector; and $\mathrm{T}$ is the number of sectors of manufacturing industry.

The index has a minimum value of zero when industrial production is well distributed among the sectors and its value gets closer to one the more unequal is this distribution.

\subsection{Exploratory Spatial Data Analysis (ESDA)}

The Exploratory Spatial Data Analysis (ESDA) is a set of techniques used to describe spatial distributions of variables, draw patterns of spatial correlation and indicate the occurrence of clusters, or outliers (Anselin, 1988). In order to the ESDA to be implemented is necessary to use dense spatial variables, as absolute variables can induce to analysis errors. Those errors tend to be correlated with the variables of scale and end up generating spurious spatial correlations. In this sense, the division of the variable of interest by some indicator of intensity such as the number of inhabitants or the size of the area of a region, for instance, solves this problem (Anselin, 2005). Thus, the ESDA is the best method to obtain measurements of global and local spatial autocorrelation, noting the influence of spatial effects by means of quantitative tools and not only by the "human eye" (Anselin, 1988; Anselin, 1995).

\subsubsection{Matrix of spatial weights}

Initially, to the application of the method, a spatial weight matrix (W) which represents a way of spatially structuring the data must be defined. The elements $\mathrm{w}_{\mathrm{i}, \mathrm{i}}$ of the main diagonal of this matrix present values equal zero, while the elements $\mathrm{w}_{\mathrm{i}, \mathrm{i}}$ of the matrix indicate how the region $\mathrm{i}$ is spatially connected with the region $\mathrm{j}$.

The definition of the spatial weight matrix is based on the continuity which, in turn, can be defined depending on the neighborhood, the geographic and socioeconomic distance or a combination of both. This definition is fundamental because the results of the analysis are influenced by this selection ${ }^{2}$. Among the

${ }^{2}$ Many results in spatial econometrics depend on the chosen spatial weight matrix, namely, the discussion regarding the typology of matrixes becomes very important and crucial to the achievement of a research. 
existing matrix, the formulations Queen and Tower can be cited: the matrix Queen considers adjacent the micro-regions that have common borders, in addition to the common vertices, whereas the matrix Tower, by definition, considers only as neighbors the micro-region with one single border.

\subsubsection{Univariate global spatial autocorrelation}

The global spatial autocorrelation can be calculated using Moran's I statistics. This statistic tests the null hypothesis of spatial randomness between the indicators against the alternative hypothesis of spatial dependence, considering global interactions. In other words, the Moran's I statistics expresses the degree of linear association between the vectors of observed values at the moment $t$ and the weighted average values of the neighborhood, or the spatial gaps ; a value of higher (lower) I than the expected value means that there is a positive (negative) autocorrelation.

$$
E(I)=\frac{-1}{(n-1)}
$$

According to Cliff and Ord (1981), officially, the univariate global Moran's I statistics can be represented by:

$$
I_{t}=\left(\frac{n}{S_{0}}\right)\left(\frac{z_{t} w z_{t}}{z_{t} z_{t}}\right) \text { para } \mathrm{t}=1,2 \ldots \mathrm{n}
$$

in which:

- $\mathrm{Z}$ is the vector of $\mathrm{n}$ observations for the year $\mathrm{t}$ in the form of deviation from the average;

- W is the spatial weight matrix; and

- $S_{0}$ is a scalar equal to the sum of all elements of $\mathrm{W}$.

When the spatial weight matrix is normalized on the line, namely, when the elements of each line total up 1, it is represented as follows:

$$
I_{t}=\left(\frac{z_{t} w z_{t}}{z_{t} z_{t}}\right) \text { para } \mathrm{t}=1,2 \ldots \mathrm{n}
$$

The analysis of significance of Moran's I indicates that the data is randomly distributed or not, and if significant, a positive signal indicates that the data are concentrated through the micro-regions; while the negative signal notifies 
the dispersion of data. The values of this statistics vary from $[-1,1]$, where -1 represents a completely negative linear coefficient of correlation, meaning that data is more dispersed, while 1 represents a completely positive coefficient of correlation, meaning that concentration is more intense (Anselin, 1995).

However, Moran's I provides only an estimate of global information among the different Brazilian micro-regions, considering the variable of interest. In this context, local interaction patterns tend to be omitted by this analysis and might hide scenarios that stand out from positive global autocorrelation. The use of LISA ${ }^{3}$ indicators could solve this issue, because through formal statistics, these indicators reveal patterns of local spatial association, through the generation of maps.

\subsubsection{Distribution Diagram of Moran}

The Distribution Diagram of Moran, shown in Picture 1, provides the spatial aspect of the interactions, through the Ordinary Least Squares regression (OLS), of the variable of interest, against its spatial gap. It is divided into four quadrants that correspond to patterns of local spatial association between certain micro-regions and their respective neighbors (Teixeira Et Al., 2008).

PICTURE 1: EXAMPLE OF A DISTRIBUTION DIAGRAM OF MORAN

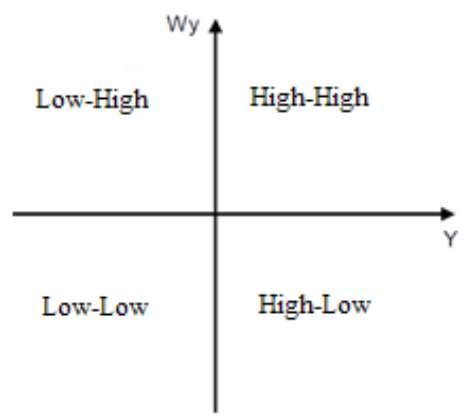

Source: Designed by the authors.

The Moran scatter plot allows visualizing the spatial association of data and shows the regression coefficient of the spatial lag Wz relative to z. According Perobelli et al. (2006), this diagram is divided into four quadrants, each of which corresponds to a pattern of spatial association, see Picture 1. The clusters of type High-High (HH) and Low-Low (LL) have positive spatial autocorrelation, indicating the presence of clusters that have similar values (or high or low), ie, spatial units with high values (low) are surrounded by ${ }^{3}$ LISA indicators will be presented on 3.2.4 subsection. 
spatial units with values high (low). The negative autocorrelation, which occurs in clusters of type Low-High (LH) and High-Low (HL) form clusters with different values, ie, spatial units with high (low) values are surrounded by units with low (high) values.

\subsubsection{Local Indicators of Spatial Association (LISA)}

In order to prove (or not) the results of global spatial autocorrelation test is necessary to calculate the LISA statistics (Local Indicator of Spatial Association), which is based by the local Moran's I. So as to confirm the degree of local spatial autocorrelation two criteria must be followed: (i) these indicators should have, for each observation, an indication of significant spatial clusters of similar values around each observation; and (ii) the sum of the LISA indicators in all the regions, should be proportional to the indicator of global spatial autocorrelation (Anselin, 1995). Thus, it can be represented by the LISA indicators through the following formula:

$$
I_{i, t}=\frac{x_{i, t}-\mu_{t}}{m_{0}} \sum_{j} w_{i, j}\left(x_{i, t}-\mu_{t}\right) \operatorname{com} m_{0}=\frac{\left(x_{i, t}-\mu_{t}\right)^{2}}{n}
$$

in which $x_{i, t}$ is the observation of a variable of interest in the micro-region $\mathrm{i}$ in year $\mathrm{t}$; and $\mu_{t}$ is the mean of the observations between the micro-regions of the year $t$ for which the sum in relation to $\mathrm{j}$ is such that only neighboring values of $\mathrm{j}$ are included.

Positive values from represent the existence of spatial clusters with similar values (high or low); negative values indicate the existence of spatial clusters with different values between the micro-region and its neighbors. Regarding the great amount of compiled information, ideally, they should be mapped in order to form the so-called map of clusters.

\section{Main results}

The data in this spatial analysis are based on the calculated indexes of Krugman (K) and Gini (G). In this study, it was used the Queen spatial weight matrix. The matrix has been chosen because it showed the highest values of the Moran's I, as recommended by Almeida (2004). However, it is important to highlight that other matrix were tested and also presented statistically significant results, showing the density of the analysis (ie, the spatial weight matrices tested were types: Queen, Rook and k-nearest neighbor with 3, 5 and 7 number of neighbors). Hereinafter, we present the results and discussions 
of the univariate analysis of the indexes of the Krugman's specialization and the Gini's concentration measured for the year 2012 (Table 1).

TABLE 1: VALUES OF MORAN'S I TO THE KRUGMAN AND GINI INDEXES, CONSIDERING SOME SPATIAL WEIGHT MATRICES FOR THE YEAR 2012

\begin{tabular}{llllll}
\hline INDEXES & QUEEN & ROOK & $\begin{array}{l}\text { 3 NEIGH- } \\
\text { BORS }\end{array}$ & $\begin{array}{l}5 \text { NEIGH- } \\
\text { BORS }\end{array}$ & $\begin{array}{l}7 \text { NEIGH- } \\
\text { BORS }\end{array}$ \\
\hline $\begin{array}{l}\text { KRUG- } \\
\text { MAN }\end{array}$ & 0.20038 & 0.20021 & 0.190732 & 0.171328 & 0.170705 \\
GINI & 0.212641 & 0.208333 & 0.197171 & 0.182634 & 0.182896 \\
\hline
\end{tabular}

Source: Designed by the authors through the use of GeoDa software and based on the data from the research.

\subsection{Univariate analysis of the Krugman's index for the year 2012}

For the year 2012, as shown in Picture 2, the Moran's I indicated a value of 0.20038 , rejecting, this way, the null hypothesis of absent spatial autocorrelation ${ }^{4}$. There is a tendency of positive global spatial dependence between the specialization of the manufacturing industry in a Brazilian micro-region and the same manufacturing industry in neighboring micro-regions.

\footnotetext{
${ }^{4}$ The significance level for the test was $0.1 \%$ with 999 permutations. This significance has been randomly estimated, in which 999 permutations from observations and locations have been processed and also the probability of occurrence of the current $I$ from the 1.000 samples has been calculated (the 999 permutations and the current $I$ ).
} 
PICTURE 2: DISTRIBUTION DIAGRAM OF MORAN TO THE KRUGMAN'S SPECIALIZATION INDEX FOR THE YEAR 2012

\section{Moran's I: 0,20038}

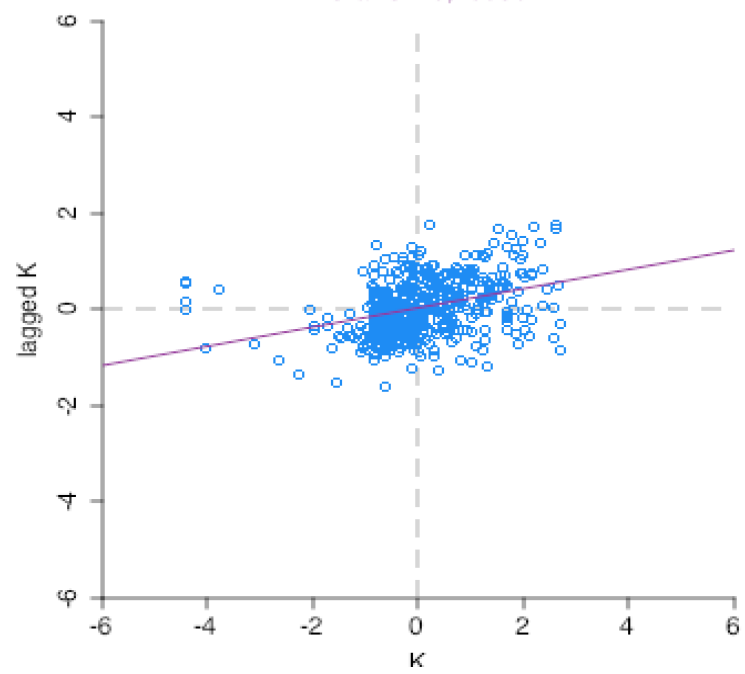

Source: Designed by the authors through the use of GeoDa software and based on the data from the research.

The result for the local configuration of the locational patterns in terms of productive specialization of the manufacturing industry in the Brazilian micro-regions in 2012 is shown by Map 1. 


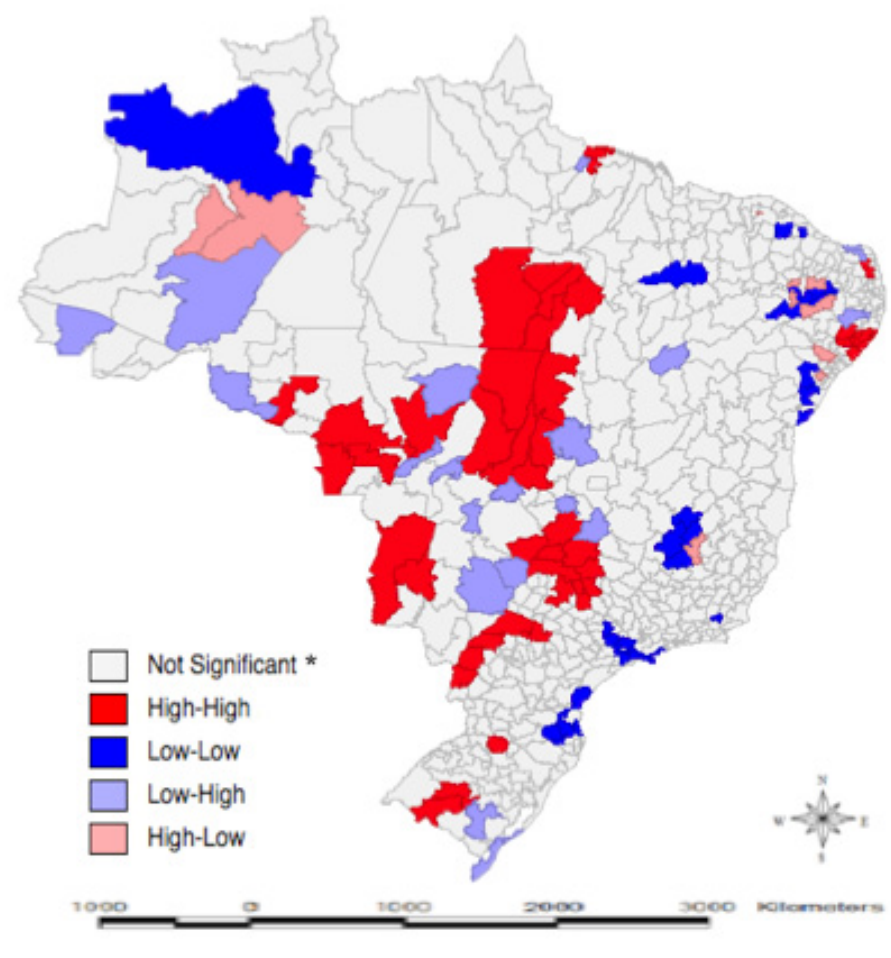

* Take into account the statistical significance of spatial clusters, allowing conclude whether a group exists or not statistically significant.

Source: Designed by the authors through the use of GeoDa software and based on the data from the research.

As can be seen in the Map 1, the specialization of the manufacturing industry has some very well-defined clusters: one with a high concentration of specialization in the High-High pattern, some others in the Low-Low pattern with low concentration of specialization, and it also presents, to a lower number, some micro-regions showing High-Low and Low-High patterns.

The High-High pattern indicates that micro-regions showing a high level of specialization in manufacturing industry are neighbors to micro-regions that also present a high level of specialization in industries from the same segment. For the year 2012, the Northeastern micro-regions with higher prominence 
regarding this scenario were: Litoral Sul (RN), Agreste Potiguar (RN), Serrana dos Quilombos (AL), Mata Alagoana (AL), Maceió (AL) and Garanhuns (PE). In the state of Mato Grosso, another High-High kind of cluster was detected, where the micro-regions of Parecis, Alto Guaporé, Alto Teles Pires, Médio Araguaia, Canarana, Tangará da Serra and Alto Pantanal were identified. These micro-regions from the Northeast and from the state of Mato Grosso were characterized by the specialization in the sectors of manufacturing of coque, oil and biofuels products (Division 19), with the manufacturing of alcohol and biofuel manufacturing, except alcohol. The manufacturing of rubber and plastic products (Division 22), with the reform of tires and manufacturing of non-metallic mineral products (Division 23), manufacture of articles of concrete, cement, cement, plaster and similar materials.

As for the micro-regions of Salgado (PA), Paraupebas (PA), Conceição do Araguaia (PA) and Castlebay (PA), they standed out concerning the specialization in manufacturing food and beverage products (Divisions 10 and 11), with the manufacture of products fish and vegetable oils and manufacturing of non-metallic mineral products (Division 23), manufacture of cement and concrete artifacts. The cluster of micro-regions of Cacoal (RO), São Félix do Xingu (PA), Miracema (TO) and Rio Formoso (TO) was identified as specialized in the preparation of leather and manufacturing leather goods, travel goods and footwear (Division 15), working mainly in tanning leather and other preparations and manufacturing of wood products (Division 16), related to the split timber activities.

The regions of Araguaína (TO), São Miguel do Araguaia (GO), Sudoeste de Goiás (GO), Meia Ponte (GO), Frutal (MG), Uberaba (MG), Ituiutaba (MG) and Uberlândia (MG) are configured as the highlights on specialization in manufacturing of textile products (Division 13), finishing services for yarns, fabrics and textile articles and household uses. The manufacturing of articles of clothing and accessories (Division 14), with the production of underwear, pieces of clothing and apparel articles produced in knitting and preparation of leather and manufacturing leather goods, travel goods and footwear (Division 15). In this group, it is possible to identify the Local Productive Arrangements (APLs) nationally known in the garment industry, namely, the APLs from the state of Goiás and the state of Minas Gerais. These APLs have been consolidated over time as important manufacturing centers of garment industry at regional, state and national levels. The garment industry, besides being a great strength for employing, is a segment that has a high power concerning local interaction and, therefore, represents dynamism to economies where inserted. A significant share of the garment industry in total employment in Goiás and Minas Gerais, the large number of firms with related activities and the dense network of urban services in force due to the industry reveal a high power impact caused by the APLs on local, regional and state economies (Redesist, 2006). 
In São Paulo, we observed a strong influence of the sectors related to foods productions (Division 10), slaughter pigs, birds and other small animals, meat products, fruit juices, vegetables and legumes and dairy. Activities and related manufacturing of metal products, except machinery and equipment (Division 25), manufacture of metal frames, heavy boiler works and artifacts stamped metal. Besides furniture manufacturing (Division 31) and Maintenance, Repair and Installation of Machinery \& Equipment (Division 33) used in the industrial production process, carried out by specialized units, usually under contract. The micro-regions that kept up with the specialization in these sectors were: São José do Rio Preto, Jaboticabal, São Joaquim da Barra, Assis, Catanduva, among others.

In the Southern region, there were found the micro-regions of Paraná - Cianorte, Apucarana, Maringá and Londrina - presenting the High-High pattern for activities related to food products (Division 10) and manufacturing of articles of clothing and accessories (Division 14), in addition to the microregion of Toledo that excelled in manufacturing of pharmachemicals and pharmaceutical products (Division 21), manufacture of medicinal products for human use and veterinary medicinal products.

Rio Grande do Sul also presented expertise in High-High pattern, with the micro-regions of Erechim, Campanha Central and Santa Maria. Such microregions focused on specialization in the sectors of preparation of leather and manufacturing leather goods, travel goods and footwear (Division 15) and manufacturing of machinery \& equipment (Division 28). This state stands out for clusters in the sectors of machinery and equipment and leather-footwear. The APL of machines and agricultural products aggregates micro-regions with both agricultural and industrial expertise, and it was precisely under the influence of developments in the planting of certain crops that the industrial segment developed and consolidated the industrial segment devoted to the manufacturing of agricultural equipment. The concentration of this industrial sector is due, in particular, to historical issues regarding the initiation of the agricultural cultivation and mechanization, as well as the strategic position in relation to Mercosul. The leather-footwear APL brings an extensive set of firms and other institutional actors operating at different stages of the footwear production chain, being a national benchmark in this segment (Redesist, 2006).

On the other hand, the Low-Low pattern refers to micro-regions that have a greater diversification of production in manufacturing industry and that are neighbors of micro-regions which are also holding high level of diversification in this segment of industry. In 2012, some micro regions presenting this classification were: Negro (AM), Canindé (CE), Barro (CE), Chapadas do Alto Itapeacuru (MA), Serra do Teixeira (PB), Piancó (PB), Patos (PB), Itaporanga (PB), Salgueiro (PE), Ribeira do Pombal (BA), Alagoinhas (BA) and Salvador (BA). The main productive activities observed were: manufacture of rubber and plastic material (Division 22), manufacture of motor vehicles, trailers and 
bodies (Division 29) and maintenance, repair and installation of machinery and equipment (Division 33).

In the Southeast, the clusters are grouped together in Bocaiúva, Diamantina, Curvelo, Três Marias and Sete Lagoas in the state of Minas Gerais; Macacu-Caceribu and Serrana in the state of Rio de Janeiro, and in Bragança Paulista, Sorocaba and Campinas in the state of São Paulo. The yields observed for the year 2012 were: manufacture of rubber and plastic material (Division 22), manufacture of metal products, except machinery and equipment (Division 25) and manufacture of machinery, appliances and equipment (Division 27). In the South, the micro-regions of Paraná - Paranaguá, the micro-regions of Santa Catarina - Joinville, Itajaí, Blumenau, Rio do Sul and Tabuleiro - appeared as representatives of the Low-Low pattern. With production mainly in manufacturing of apparel and accessories (Division 14) and manufacture of other transport equipment except motor vehicles (Division 30) activities, working on construction of ships and floating structures and vessels for sport and leisure.

The High-Low pattern presents the micro-regions with a high level of specialization in manufacturing that are surrounded by micro-regions with a higher level of diversification in this industry segment. In 2012, the micro-regions classified in this pattern were: Coari (AM), Oiapoque (AP), Serra de São Miguel (RN), Sousa (PB), Brejo Santo (CE), Pajéu (PE), Sergipana do Sertão do São Francisco (SE), Japaratuba (SE) and Bananal (SP). These clusters were highlights in productive specialization in the sectors of manufacturing food products (Division 10) and manufacturing of non-metallic mineral products (Division 23). One of the justifications for the expertise in Division 10 in the Northeast micro-regions is the strength of its agribusiness to local economies such as the cocoa industry in Bahia and the honey industry in Piauí, where this is one of the most prominent activities in the economy of the state, in view of the recent expansion of production and placement of bee products in new markets, including abroad, results of competitiveness achieved by some productive local clusters. Regarding the specialization in Division 20, it is related to the activity of oil and gas production, especially in Bahia, as this activity has extreme importance for the state economy, since it is largely responsible for payroll and payroll taxes (Redesist, 1998). In Division 23 stands out with the manufacture of articles of concrete, cement, cement, plaster and similar materials and the manufacture of refractory ceramic products not for structural use in construction.

The Low-High pattern presents the micro-regions with a high level of diversification of production in manufacturing industry that are surrounded by micro-regions with a high level of expertise in this industry segment. In 2012, the micro-regions that presented such features were: Tarauacá (AC), Sena Madureira (AC), Furos de Breves (PA), Belém (PA), Macau (RN), Baixa Verde (RN), Guajará-Mirim (RO), Colorado do Oeste (RO), Chapadas do Ex- 
tremo Sul Piauiense (PI), Sinop (MT), Rosário Oeste (MT) and Primavera do Leste (MT) with the preparation of leather and manufacture of leather goods, travel items and footwear (Division 15) and manufacture of wood products (Division 16). Other micro-regions that presented Low-High pattern and stood out in Divisions 14, 25 and 31 were Porangatu (GO), Aragarças (GO), Alto Araguaia (GO), Goiânia (GO), Paranaíba (MS) and Serras de Sudeste (RS). These divisions include activities relating to: making articles of clothing and accessories; manufacture of metal products, except machinery and equipment and furniture manufacturing, respectively.

The univariate analysis of the Krugman's specialization index, then, comparatively evaluates the specialization of the productive structure of a micro-region with other micro-regions, which means, one region against another, which signals and allows us to make some considerations about it. In specialization, from both the point of view of firms and clusters and the manufacturing industry, it would be interesting not have production specialization - regional differentiation of industrial structures among regions of a specific industrial activity - as it enables the development of the existing industrial area in this region. A region considered specialized by the Krugman's index can become a hub of a determined activity for a given industrial sector, failing to generate great benefits and advantages in the production process, getting up somewhat limited and not diversified. So this would be more attractive to own a micro diversified productive base as strategy development and industrial production, as the face of future uncertainties and dynamics of the economy, no one knows what can happen with a specific industry.

Thus, the results suggest that the standard Low-Low is very good for the growth and development of more diversified production process of the manufacturing industry as a whole. The diversification of industrial activities in a micro-regions is interesting, because it would have other activities to boost their economy any time the sector in which the region specializes is in a situation economically unfavorable.

\subsection{Univariate analysis of the Gini's index for the year 2012}

For the year 2012, the Moran's I indicated a value of 0.212641 as shown in Picture 3. That means that it is possible to reject the null hypothesis of absent spatial autocorrelation ${ }^{5}$. There is a tendency of global positive spatial dependence between the concentration of manufacturing industry in a Brazilian micro-region and that same manufacturing industry in neighboring micro-regions.

5 The significance level for the test was $0.1 \%$ with 999 permutations. This significance has been randomly estimated, in which 999 permutations from observations and locations have been processed and also the probability of occurrence of the current $I$ from the 1.000 samples has been calculated (the 999 permutations and the current $I$ ). 
PICTURE 3: DISTRIBUTION DIAGRAM OF MORAN TO THE GINI'S CONCENTRATION INDEX (G) FOR THE YEAR OF 2012

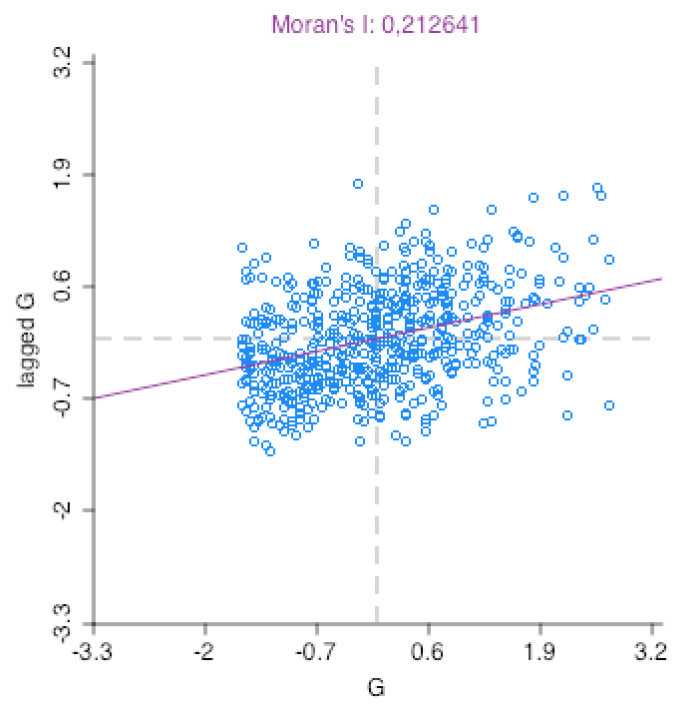

Source: Designed by the authors through the use of GeoDa software and based on the data from the research.

The result for the local configuration of the locational patterns in terms of productive concentration of the manufacturing industry in the Brazilian micro-regions in 2012 is shown by the Map 2. As shown in Map 2, the concentration of manufacturing industry has some very well-defined of High-High and Low-Low patterns clusters, in addition to presenting, to a lower number, some micro-regions in the High-Low and Low-High patterns.

The High-High pattern indicates the micro-regions with a high level of concentration of production in manufacturing industry that are neighbors to microregions which also have a high concentration of industries of the segment. For the year 2012, the Northeastern micro-regions with higher prominence in this pattern were: Sobral (CE), Agreste Potiguar (RN), Natal (RN), João Pessoa (PB) and Litoral Norte (PB). These clusters are focused on productive activities related to manufacturing of textile products (Division 13), manufacturing of articles of clothing and accessories (Division 14) and preparation of leather and manufacturing leather goods, travel goods and footwear (Division 15). In addition to these micro-regions, other northeastern micro-regions could be identified as important actors in the production process: Santana do Ipanema (AL), Mata Alagoana (AL), São Miguel dos Campos (AL), Arapiraca (AL) and Garanhuns (PE). In the state of Mato Grosso another High-High pattern cluster was detected in the micro-regions of Parecis, Alto Guaporé, Tangará da Serra, Arinos, Sinop, Alto Teles Pires, Rosário Oeste, Aripuanã, Norte Ara- 
guaia, Médio Araguaia and Canarana. These micro-regions in the Northeast and in the state of Mato Grosso were characterized by the concentration in the sectors of manufacturing of coque, oil and biofuels products (Division 19), with the manufacturing of alcohol, manufacturing of rubber and plastic products (Division 22) and manufacturing of non-metallic mineral products (Division 23), manufacture of articles of concrete, cement, cement, plaster and similar materials and manufacture of non-refractory ceramic products for structural use in construction.

The micro-regions of Salgado (PA), Furos de Breves (PA), Conceição do Araguaia (PA), Guarajará-Mirim (RO) and Cacoal (RO) have excelled in the concentration of manufacturing food and beverage products (Divisions 10 and 11), with slaughter of cattle, making crude vegetable oils, fish products, dairy products and the manufacture of soft drinks and other non-alcoholic beverages. Also observed related to the manufacturing of wood products (Division 16), split wood and the manufacture of laminated wood and wood veneer plywood, pressed and crowded, and manufacturing of non-metallic mineral products (Division 23), with the manufacture of cement and concrete artifacts, concrete, cement, plaster and similar materials. In Pará, the food production industry is driven by agribusiness, especially of cassava, palm tree, nuts and fibers. In Rondônia, a very strong wood industry can be identified due to the abundance of raw material. This activity reached its peak with about 3,000 firms installed, accounting for $40 \%$ of industrial employment and tax revenue. Moreover, the wood has represented about $90 \%$ of exports of the state. Currently, the wood industry accounts for about $28 \%$ of industrial GNP in the state (Fiero, 1997). 

THE MANUFACTURING INDUSTRY TRANSFORMATION IN BRAZILIAN MICRO-REGIONS IN 2012

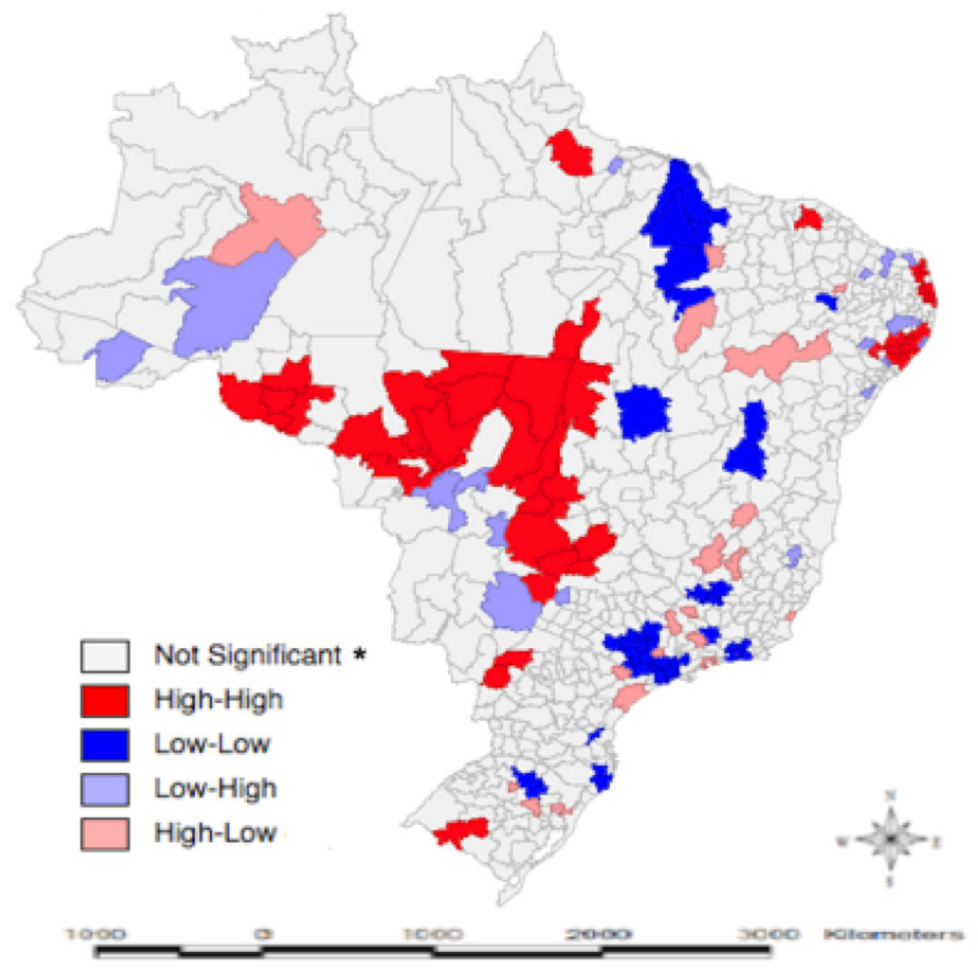

* Take into account the statistical significance of spatial clusters, allowing conclude whether a group exists or not statistically significant.

Source: Designed by the authors through the use of GeoDa software and based on the data from the research.

The productive cluster in Rio Vermelho (GO), Aragarças (GO), Iporá (GO), Sudoeste de Goiás (GO), Meia Ponte (GO), Quirinópolis (GO), Rio Formoso (TO), Ituiutaba (MG), Paranaíba (MS), Nova Andradina (MS) and Presidente Prudente (SP) are shaped as the highlights on productive concentration of textile products (Division 13), with the finishing of yarns, fabrics and textile articles and supplies for domestic use, manufacturing of articles of clothing and accessories (Division 14), obtaining pieces of clothing and apparel articles produced in knitting and tricotagens except socks. Additionally, the preparation of leather and artifact manufacturing of leather, travel goods and footwear (Division 15), tanning and other preparations leather and manufacture of leather footwear. 
In relation to the South, the micro-regions in Paraná - Paranavaí and Toledo - presented the High-High pattern for activities regarding the manufacturing of articles of clothing and accessories (Division 14), with the production of parts and apparel manufacturing of garment accessories, except for safety and protection, the manufacturing of machinery \& equipment (Division 28), manufacture of machinery, refrigeration and ventilation products for industrial and commercial use and manufacture of machinery and equipment for agriculture and livestock. Besides manufacturing of furniture (Division 31), manufacturing furniture predominantly of wood and metal. In Rio Grande do Sul, the observed pattern was for High-High productive concentration in the micro-region of Campanha Central and Campanha Meridional in relation to the sectors of manufacturing of food and beverage products (Divisions 10 and 11), with slaughter of pigs, birds and other small animals, rice processing and manufacturing of rice, manufacture of bakery products and manufacturing soft drinks and other non-alcoholic bebibas. Also, activities related to printing \& reproduction of recordings (Division 18), printing of materials for other uses and prepress services.

On the other hand, the Low-Low pattern refers to the micro-regions presenting a reduced productive concentration level in manufacturing industry surrounded by micro-regions also presenting low concentration in the industries of this segment. In 2012, some Northeastern micro-regions which obtained this classification were: Gurupi, Dianópolis, Guanambi (BA), Cariri (CE), Araripina (PE) and the micro-regions in the state of Maranhão: Itapecuru Mirim, Baixada Maranhense, Médio Mearim, Alto Mearim, Grajaú and Chapadas das Mangabeiras. The most productive activities were identified: food products (Division 10), slaughtering of cattle, pigs and excluding manufacture of non-metallic mineral products (Division 23), manufacture of articles of concrete, cement, cement, plaster and similar materials and manufacture of non-refractory ceramic products for structural use in construction.

In the Southeast, the Low-Low pattern clusters were grouped in Belo Horizonte, Itaguara and Andrelândia, in Minas Gerais; Vitória, in Espírito Santo; Rio de Janeiro, Vassouras and Serrana, in Rio de Janeiro; and Ararauara, Jaú, São João da Boa Vista, Pirassununga, Rio Claro, Piracicaba, Moji-Mirim, Jundiaí, Guarulhos, Moji das Cruzes, Itapecerica da Serra, Sorocaba, Tatuí,São Paulo ${ }^{6}$, São José dos Campos and Santos, in the state of São Paulo. The main sectors active in the state of São Paulo in 2012 were: manufacture of food products (Division 10), manufacture of matal, except machinery and equipment (Division 25), manufacture of machinery and equipment (Division 28) and vehicle manufacturing automotive, trailers and bodies (Division 29). In the South,

6 In general, one can say that a micro-regions with capacity of high employment and economic activities and industrial dense presents little concentrated. A typical example of this configuration is the state of São Paulo. Thus, micro-regions with a very dense production tend to be varied (for further discussion read Garcia et al., 2009). Instead, industrial micro-regions tend to be less dense more concentrated productive configurations, since the absence of some types of industrial or the presence of a few larger companies may interfere with the level of concentration. A typical example of this characteristic can be observed in Northeast micro-regions. 
the micro-regions of Paranaguá in Paraná, Blumenau and Tabuleiro in Santa Catarina and Caxias do Sul and Guaporé in Rio Grande do Sul also showed this pattern of concentration.

The High-Low pattern presents micro-regions with a high level of productive concentration in manufacturing industry that are surrounded by microregions with a low level of industry concentration in this segment. For the year 2012, the micro-regions which are worth mentioning: Coari (AM), Lençóis Maranhenses (MA), Presidente Dutra (MA), Alto Parnaíba Piauiense (PI), Pio IX (CE), Lavras Mangabeira (CE) and Juazeiro (BA). These micro-regions were characterized by the concentration in the sectors of manufacturing of coque, oil and biofuels products (Division 19), with the manufacturing of products from petroleum refining and alcohol production and manufacturing of rubber and plastic products (Division 22), with the manufacture of plastic containers. Additionally, the manufacturing of non-metallic mineral products (Division 23), manufacture of articles of concrete, cement, cement, plaster and similar materials and manufacture of non-refractory ceramic products for structural use in construction. The micro-regions in Minas Gerais of Grão Mogol, Campo Belo and São Lourenço are seen as great highlights in the productive concentration in manufacturing of textile products (Division 13), manufacturing of articles of clothing and accessories (Division 14) and preparation of leather and manufacturing of leather and leather artifacts, travel goods and footwear (Division 15).

The cluster of Baía da Ilha Grande (RJ), Amparo (SP), Itapetininga (SP) and Registro (SP) had focused on the manufacturing of food products (Division 10), with the slaughter of pigs, birds and other small animals, manufacturing of meat products, dairy products and raw sugar and manufacturing of nonmetallic mineral products (Division 23), manufacture of flat glass and safety glass articles and articles of concrete, cement, asbestos, gypsum and. In the South, the micro-region in the state of Paraná, Lapa, and the micro-regions in the state of Rio Grande do Sul, Não-me-Toque, Lajeado-Estrela and Gramado-Canela, concentrates production in the sectors of manufacturing of clothing and accessories (Division 14), with the production of pieces of clothing and the preparation of leather and preparation of leather and manufacturing of leather goods, travel goods and footwear (Division 15), and other preparations tanning of leather, manufacture of articles for travel goods, handbags and similar to any materials and manufacturing leather footwear. Besides these activities, there was the production of manufacturing of metal products, except machinery \& equipment (Division 25), manufacture of metal structures, cutlery and tools.

The Low-High pattern indicates micro-regions with a limited level of productive concentration in manufacturing industry that are surrounded by micro-regions with a high level of concentration in this industry segment. For the year 2012, the micro-regions that showed these characteristics were: Sena 
Madureira (AC), Purus (AM), Belém (PA), Castanhal (PA), Litoral of Camocim and Acaraú (CE), Umarizal (RN), Vale do Açu (RN), Baixa Verde (RN) and Serrana do Sertão Alagoano (AL), with productive activities: manufacture of coke, petroleum products and biofuels (Division 19), manufacture of alcohol and manufacture of rubber products and plastic (Division 22) and products of non-metallic minerals (Division 23). Other micro-regions that stood out in this standard Low-High were: Barra de São Francisco (ES), Primavera do Leste (MT), Alto Araguaia (GO), Três Lagoas (MG), Jales (SP), Santa Maria (RS) and Serras de Sudeste (RS).

The univariate analysis of the Gini's concentration index, then, evaluates internally, and separately, the industrial structure of a micro-region, which also signals and allows us to make some considerations about the regional industrial concentration levels observed. From the perspective of firms and clusters, the industrial concentration - in the form of the existence of centripetal forces towards productive agglomeration - in a specific micro-region can generate some specific benefits to their location because they operate with increasing returns at a scale level and externalities, such as easiness to find skilled workers, availability of resources and specialized inputs and the presence of informational and technological spillovers among firms.

From the point of view of the manufacturing industry as a whole, the concentration of industrial activities in a micro-region is interesting, because the cluster of a particular industry sector attracting investment and public policies related to development of this activity, increasing productivity and quality of products and processes, increasing the difficulty of finding such products with competitive prices in other regions, creating new niches of market for the product, strengthening the chain of related activities and complement the core business, expanding the tacit knowledge of the sector and its competitiveness.

In this case it could be argued that the standard High-High $(\mathrm{HH})$ would be ideal, because there would be a location of concentrated industries in nearby regions. Thus the concentration would affect the basic strategy of dynamic growth industry, providing character Jacobian externalities. Therefore, the best result would be a micro-region that could present a high level of concentration in relation to micro-regions, because then it would be "unique" and stand out in its industry sector, expanding its tacit knowledge, differentiated resources, know-how and techniques for its activity.

\section{Final considerations}

This study aimed to present and analyze the spatial distribution of the indexes of specialization and concentration of sectors of the Brazilian manufacturing industry based on the Krugman's specialization index and Gini's concentration index in the year 2012. For this, we calculated the indices for the 558 
Brazilian micro-regions in the year of analysis. In addition to these indicators, this work made use of Exploratory Spatial Data Analysis (ESDA) to detect spatial patterns of behavior of the indicators of interest, supporting, or not, the influence of the environment and space on them.

The first statistic to be considered was the Moran's I, which indicates the degree of global spatial autocorrelation between the index to be analyzed and its spatial gap, in a univariate context. However, this statistic cannot detect local patterns of spatial association, being necessary to use LISA indicators, represented by the Distribution Diagram of Moran and the map of clusters; such indicators can establish patterns of local spatial association that Moran's I cannot, providing the configuration of the distribution indexes of interest within a didactic way.

The Moran's I indicated a value of 0.20038 for the Krugman's specialization index and 0.212641 for the Gini's concentration index, both for the year 2012. Thus, rejected the null hypothesis of absent spatial autocorrelation at a significance level of $5 \%$. The map of clusters for the year of 2012, in terms of specialization in the manufacturing industry, was presented as follows: High-High pattern concentrated mainly in the Northeast - in the micro-regions of the state of Alagoas - and in the micro-regions belonging to the states of Mato Grosso, Minas Gerais, Paraná and Rio Grande do Sul; Low-Low pattern clusters were found in some northeastern micro-regions (PB, PE, CE and BA) and micro-regions in the states of São Paulo and Santa Catarina; the High-Low pattern was detected in some micro-regions of Pernambuco, Ceará and Sergipe, whereas the main micro-regions that showed the Low-High pattern are located in some states of the Northern Region (CA, RO and PA), the Midwest Region (MT, GO and MS) and the state of Rio Grande do Norte.

In relation to the concentration of manufacturing industry, the map of clusters for the year 2012 showed the following results: High-High pattern was identified in some northeastern micro-regions (AL, CE, RN and PB), in the state of Paraná and Rio Grande do Sul, and in the North (PA and RO) and Midwest (MT, MS and GO); the Low-Low pattern was very present in some northeastern micro-regions (CE, PE, MA and BA) and in the Southeast, mainly in the state São Paulo, the micro-regions identified in the High-Low pattern proved to be concentrated in the states of Maranhão, Piauí, Bahia and Minas Gerais (Grão Mogol, Campo Belo and São Lourenço); whereas some micro-regions in the states of Alagoas, Pará and Rio Grande do Norte had the Low-High pattern industry concentration.

The result of applying this instrument for Brazilian micro-regions for the year 2010 was the identification of clusters that showed a highly specialized productive structure and other industrial structure which showed high industrial diversification. There is a perception from the empirical application of the methodology used, that some micro-regions known to be more developed tend to have a more diversified production structure, which reveals the 
importance of local Jacobian externalities related to the pool of local capabilities and tendency to technological innovations. On the other hand, other less-developed micro-regions demonstrated, in general, to be importantly related to externalities, with a high degree of specialization and concentration of local capabilities and tendencies of slowed the introduction of technological innovation in the production process.

Moreover, a proper diagnosis of the specialization and the concentration of manufacturing industry in Brazil collaborates in identifying local development processes, allowing both the public and the private sector to guide their spending and investment to boost those economies, that means, an accurate diagnosis help to create, target and leverage public policies and investments to a particular location. This helps to reduce disparities between regions, leveraging what each region can potentially offer and develop.

\section{References}

Almeida, E. S. de. (2004). Curso de Econometria Espacial Aplicada (Apostila). Universidade de São Paulo (USP), Escola Superior de Agricultura "Luiz de Queiroz" (ESALQ), Piracicaba.

Amarante, P. A.; Batista Da Silva, M. V. (2011). "Economias de aglomeração nas atividades econômicas dos municípios brasileiros no ano de 2009: evidências a partir de equações salariais”. In: VII Encontro de Economia Baiana, Salvador.

Anselin, L. (1988). Spatial econometrics: methods and models. Kluwer Academic, Boston.

Anselin, L. (1990). "Spatial dependence and spatial structural instability in applied regression analysis”. Journal of Regional Science, v. 30, pp. 185-207.

Anselin, L. (1995). "Loca lindicators of spatial association - LISA". Geographical Analysis, v. 27 (2), pp. 93-115.

Anselin, L. (1998). “Interactive techniques and exploratory spatial data analysis”. In: Longley P.A.; Goodchild M. F.; Maguire D.; Jand Wind D. W (eds). Geographical Information System: principles, techniques, management and applications. Wiley: New York, pp. 253-365.

Anselin, L. (2005). Exploring Spatial Data with Geo Da: a Workbook. University of Illinois, Urbana-Champaign.

Basso, D.; Silva Neto, B.; Stoffel, J. (2005). “Concentração e especialização em setores industriais na Região Noroeste Colonial do Rio Grande do Sul”. Indicadores Econômicos FEE, v. 33 (3), pp. 163-174.

Baumont, C.; Ertur, C.; Le Gallo, J. (2011). The European regional convergence process, 1980-1995:do spatial regimes and spatial dependence matter?University of Burgundy. Jul. 2002. URL [on-line]: <http://129.3.20.41/eos/em/papers/0207/0207002.pdf>. Acesso em: jul. 2011.

Bertella, M. A.; Teixeira, R. F. A. P. (2010). “A Indústria do Vestuário no Brasil e sua Concentração Espacial”. In: XIII Encontro Regional de Economia-ANPEC 
Sul, Porto Alegre - RS. Anais ... Associação dos Centros de Pós-Graduação em Economia no Brasil (ANPEC).

Cliff, A.; Ord, J. (1981). Spatial processes, models and applications. London: Pion.

Crescenzi, R.; Rodrígues-Pose, A.; Storper, M. (2007). "The territorial dynamics of innovation: a Europe- United State comparative analyses”. Journal of Economic Geography, n. 7, pp. 673-709

Fiero (1997). Federação das Indústrias do Estado de Rondônia. Perfil Socioeconômico.

Fujita, M.; Krugman, P.; Venables, A. J. (2002). Economia Espacial: urbanização, prosperidade econômica e desenvolvimento humano no mundo. São Paulo: Futura.

Fujita, M.; Thisse, J. F. (2002). Economics of Agglomeration: cities, industrial locations and regional growth. Cambridge: Cambridge University Press.

Garcia, R.; Araujo, V.; Mascarini, S. (2009). "Padrões de Localização Industrial e Distribuição Regional da Atividade Produtiva: Uma Análise Empírica Aplicada ao Estado de São Paulo". In.: XXXVII Encontro Nacional de Economia, Foz do Iguaçu, Paraná. ANPEC.

Haddad, P. R. (1989). "Medidas de Localização e de Especialização”. In: Haddad, P. R. et al. (Organizadores) Economia Regional: Teorias e Métodos de Análise. Fortaleza, Bnbetene.

Hoover, E. M. (1948). The Location of Economic Activity. New York: McGraw-Hill.

Jacobs, J. (1969). The Economy of Cities. New York, United States: Vintage.

Krugman, P. (1991a). Geography and Trade. London, England: The MIT Press.

Krugman, P. (1991b). "Increasing returns and economic geography”. Journal of Political Economy, Chicago, v.99 (3), pp. 483-499.

Marshall, A. (1920). Princípios de economia: tratado introdutório. São Paulo: Abril Cultural.

Midelfart-Knarvik, K. H.; Overman, H. G.; Redding, S. J.; Venables, A. J. (200o). “The Location of European Industry". Economics Papers 142, European Commission.

Moran, P. (1948). "The interpretation of statistical maps". Journal of the Royal Statistical Society, n. 10, pp. 243-251.

Perobelli, F. S.; Ferreira, P. G.; Faria, W. R. (2006). “Análise de Convergência Espacial do PIB per capita em Minas Gerais: 1975-2003”. In: XI Encontro Regional de Economia. Fortaleza. Nordeste: Estratégias de Desenvolvimento Regional. Fortaleza: BNB.

Redesist. Rede de pesquisa em Sistemas Produtivos e Inovativos Locais (1998). Estudos de Casos, Sistemas Locais de Inovação do Nordeste, Fruticultura Tropical no Nordeste. Disponível em: <www.redesist.ie.ufrj.br>. 1998. Acesso em: outubro de 2011.

Redesist. Rede de pesquisa em Sistemas Produtivos e Inovativos Locais (2006). Estudos de Casos, Avaliação e Proposição de Políticas. Disponível em: <www. redesist.ie.ufrj.br>. 2006. Acesso em: novembro de 2011. 
Silveira Neto, R. M. (2005). “Concentração industrial regional, especialização geográfica e geografia econômica: evidências para o Brasil no período 1950-2000”. Revista Econômica do Nordeste, Fortaleza, v.36 (2), pp. 189-208.

Sousa, F. L. de. (2002). A Localização da Indústria de Transformação Brasileira nas Últimas Três Décadas. São Paulo. Dissertação de Mestrado. Escola de Pós-Graduação em Economia (EPGE) - Fundação Getúlio Vargas (FGV).

Suzigan, W.; Furtado, J.; Garcia, R.; Sampaio, S. (2001). “Aglomerações industriais no estado de São Paulo”. Economia Aplicada, v. 5 (4), pp. 695-717.

Teixeira, R. F. A. P.; Almeida, E. S.; Oliveira Jr. L. B.; Alvim, M. I. S. A. (2008).“Análise Espacial da Produtividade de Óleo Vegetal para Produção de Biodiesel na Zona da Mata Mineira”. Gestão Organizacional. v. 6 (3), pp. 278-299.

Venables, A. J. (1996). Equilibrium Locations of Vertically Linked Industries. International Economic Review, v.37 (2), pp. 341-359. 